Fisheries Research

February 2018, Volume 198, Pages 24-30

http://dx.doi.org/10.1016/i.fishres.2017.10.019

http://archimer.ifremer.fr/doc/00407/51864/

(C) 2017 Elsevier B.V. All rights reserved

\title{
Survivability of discarded Norway lobster in the bottom trawl fishery of the Bay of Biscay
}

\author{
Mérillet Laurène ${ }^{1,{ }^{*}}$, Méhault Sonia ${ }^{1}$, Rimaud Thomas ${ }^{2}$, Piton Corentine ${ }^{2}$, Morandeau Fabien ${ }^{1}$, \\ Morfin Marie ${ }^{1}$, Kopp Dorothée ${ }^{1}$
}

${ }^{1}$ Ifremer, Unité de Sciences et Technologies halieutiques, Laboratoire de Technologie et Biologie Halieutique, 8 rue François Toullec, 56100 Lorient, France

${ }_{2}^{2}$ Association du Grand Littoral Atlantique, 6 rue Alphonse Rio, 56100 Lorient, France

*Corresponding author : Laurène Mérillet, email address : laurene.merillet@gmail.com

\begin{abstract}
:
In the context of the landing obligation set by the new Common Fisheries Policy (CFP), Norway lobster Nephrops norvegicus was identified as a species likely to have high survival rate when discarded in the bottom trawl fishery of the Bay of Biscay. Previous studies in this area reported a survival rate between $30 \%$ and $51 \%$, but the experiments were done on a limited monitoring period and the seasonal variations were not investigated. This study was designed to obtain a reliable value for survival rate after a 14-day monitoring period in onshore tanks allowing considering delayed mortality. The study also tested the effect on the survival rate of using a discarding chute system, a sorting device that was made mandatory on the 1st of January 2017 for Nephrops trawlers in the Bay of Biscay. This device, which enables fishermen to discard undersized Nephrops back to the sea while sorting, led to an increased average survival rate $(51.2 \%)$ compared with the standard sorting practice $(36.9 \%)$. The impact of biological, environmental and fishing operation related variables on survival from the first day of captivity to the end of the monitoring period was examined using a generalized linear model. The results of the GLM indicate that injuries, season and duration of the air exposure, significantly influence the survival from the 1st day of captivity to the end of the monitoring period. The survival rate was higher for noninjured Nephrops as well as for Nephrops that have undergone short air exposure, in summer and autumn.
\end{abstract}

\section{Highlights}

- Survival of discarded Nephrops was monitored for 14 days in tanks. Injuries and air exposure reduced survival significantly. Survival was highest in summer and autumn. Use of a discarding chute system improved survival.

Keywords : Nephrops norvegicus, Sorting process, Captivity, Vitality, Season, Discard survival 


\section{Introduction}

The new Common Fisheries Policy (CFP) brought into force the $1^{\text {st }}$ of January 2014 gradually established a landing obligation to encourage the long-term reduction of discards. However, according to article 15 paragraph 4(b), exemptions to the landing obligation can be obtained for species in which "scientific evidence demonstrates high survival rates, taking into account the characteristics of the gear, of the fishing practices and of the ecosystem" (European Commission, 2013). In particular, Norway lobster Nephrops norvegicus was identified by the ICES Workshop on Methods for Estimating Discard Survival (WKMEDS) as a species susceptible of a high survival rate (ICES, 2015). Previous studies investigated the influence of biological parameters on Nephrops survival rate after discard and found that size, sex and physical injuries all had a significant influence (Campos et al., 2015; Méhault et al., 2016; Milligan et al., 2009; Valentinsson and Nilsson, 2015). Environmental parameters, such as air temperature (Giomi et al., 2008) and salinity (Harris and Ulmestrand, 2004), have also been shown to influence survival rate. Light, of the intensity level found at the sea surface, damages Nephrops' eyes, but no impact on their survival has been demonstrated (Chapman et al., 2000; Gaten et al., 2013). Variations in ability to recover and survive across the seasons are acknowledged (Albalat et al., 2010; Castro et al., 2003; Lund et al., 2009), but the causes of such differences remain unclear and probably involve biological and environmental factors such as moult status, size (Milligan et al., 2009) or air temperature. Finally, trawling characteristics such as catch composition, tow duration, speed, the type of selective device used on the fishing gears (Campos et al., 2015, Valentinsson and Nilsson, 2015) or handling practices on deck (Bergmann and Moor, 2001), for instance duration of air exposure (Méhault et al., 2016), also have a major effect on survival. 
The Nephrops catches are of particular importance in the North of the Bay of Biscay, where it accounted for $28 \%$ of the total landings in term of weight for the Nephrops bottom trawl metier in 2015 (Cornou et al., 2016). In 2012, 191 trawlers targeted Nephrops and generated more than $€ 30$ million in market value (Leblond et al., 2012). However, this mixed fishery has a historically high level of bycatch, composed of undersized Nephrops and other commercial species such as hake (Vogel et al., 2017). To improve the selectivity of this fishery, in 2008, the French national fishing committee made it mandatory to use one of the following selective devices: codend mesh size of $80 \mathrm{~mm}$ (instead of the $70 \mathrm{~mm}$ used up to 2008), flexible grid or bottom square mesh panel (JORF, 2008). In 2011, a square mesh cylinder was added to the list (JORF, 2011). In addition to these devices, the use of a $100 \mathrm{~mm}$ top square mesh panel for hake escapement has been mandatory since 2006 (European Commission, 2006). Furthermore, the minimum landing size was set at $9 \mathrm{~cm}$ (total length) to preserve the stock. Despite these improvements, discard rates remained high, accounting for about $30 \%$ in weight of all the Nephrops caught in 2015 (Cornou et al., 2016). The discarded Nephrops that survive can contribute to stock replenishment, making it particularly important to favour their survival. In this context, the European Commission incited initiatives that improve discarded Nephrops survival. The use of a discarding chute system was proposed by fishermen to decrease air exposure and injuries since these factors are known to be amongst the main drivers of Nephrops survival (Campos et al., 2015; Méhault et al., 2016; Ridgway et al., 2006a, 2006b; Wileman et al., 1999). This device is joined to the sorting table and makes it possible to discard individuals back to the sea throughout the on-board sorting process. This minimises the duration of air exposure as well as the possibility of being injured during the time spent on the deck, compared with the 
standard sorting practice that consisted in discarding Nephrops back to the sea at the end of the sorting process. The use of this sorting device became mandatory on the $1^{\text {st }}$ of January 2017 (JORF 2016).

To measure survival rate, two methods were chosen for this study among the three identified by the Expert Working Group 13-16 (EWG13-16) of the Scientific, Technical and Economic Committee for Fisheries (STECF, 2013): vitality assessment and captive observation. Previous studies on discarded Nephrops survival in the Bay of Biscay that used a captive observation method in open water reported a survival rate between 30\% and 51\% (Gueguen and Charuau 1975; Méhault et al., 2016). However, these earlier studies were too short (3 days) to allow the asymptote of the survival rate to be reached, or to investigate variability between the different fishing seasons, or consider different sorting practices.

This study was designed to obtain a reliable value for survival rate, including its potential variations across seasons and different sorting practices. Individuals were sampled in three different seasons and two sorting practices were simulated: (1) the standard scenario, which consists of discarding the unwanted catch back into the sea at the end of the sorting process; and (2) the discarding chute system scenario, with individuals being discarded back to the sea during sorting. This study therefore investigated the influence of an environmental parameter (season), fishing operation characteristics (sorting practice, duration of air exposure, composition of the haul) and biological parameters (length, sex and injury) on Nephrops survival from the first day of captivity to the end of the monitoring period. 


\section{Materials and Methods}

\subsection{Sampling strategy and material}

Sampling was conducted on the "Grande Vasière" Nephrops ground in the North of the Bay of Biscay (Fig. 1), in depths of 78-110 m, on board two commercial trawlers. The sampling was done in three different seasons, in April, June and September 2016 (hereafter named spring, summer and autumn, respectively). The hauls were conducted under regular commercial conditions: the duration was set at 3 hours, with a speed around 3.5 knots and both vessels were rigged with a twin bottom trawl equipped with a codend mesh size of $80 \mathrm{~mm}$ and a $100 \mathrm{~mm}$ top square mesh panel. On-board handling practices were kept as usual to obtain data representative of this fishery. The main characteristics of each fishing operation were recorded: the air temperature at the sorting time, the duration of air exposure, as well as the catch composition defined here by the ratio between the weight of Nephrops caught and the weight of the total catch. 


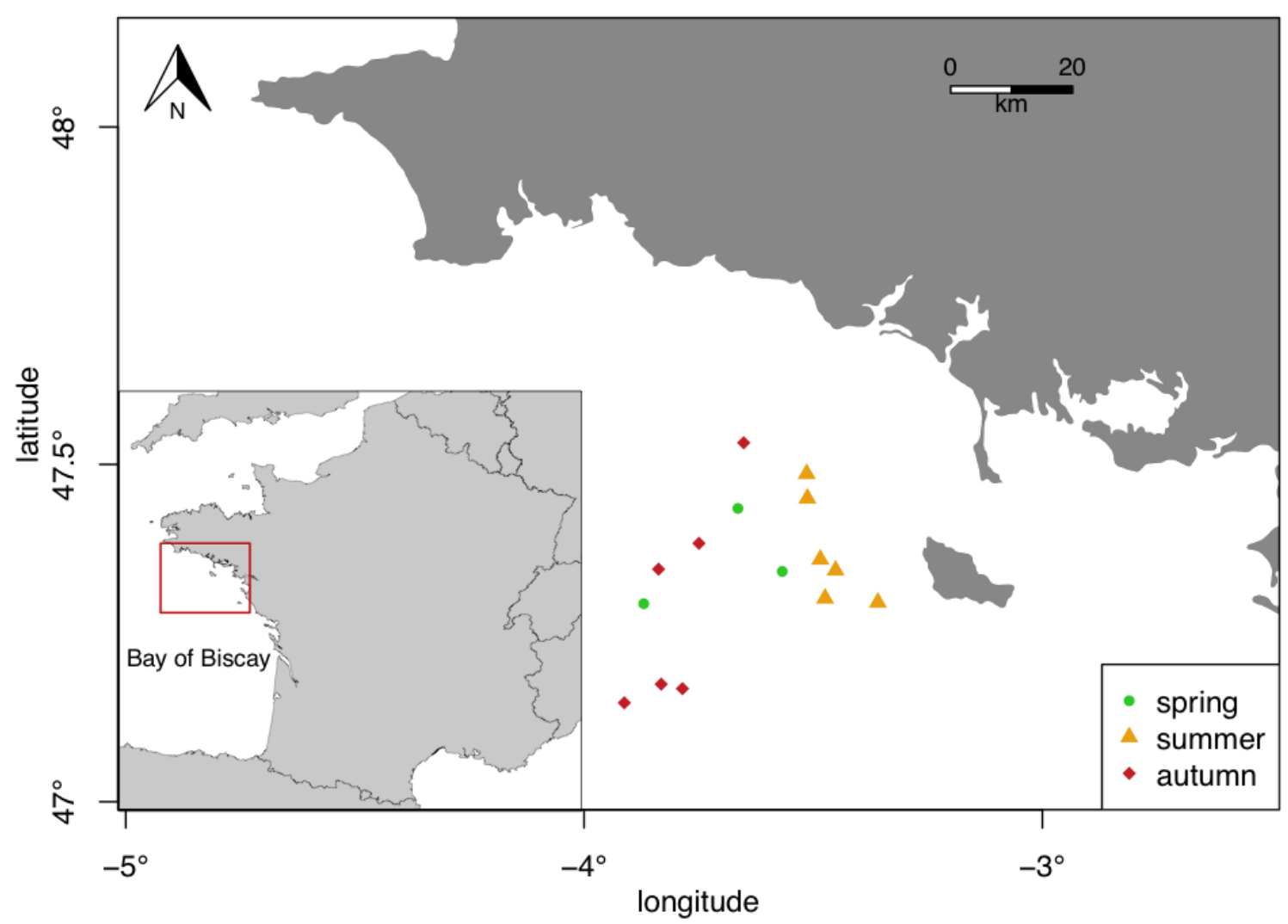

Figure 1:Map of the Bay of Biscay with sampling sites location at each season

\subsubsection{Control group sampling}

To disentangle the part of the mortality caused by the catch from any caused by captivity, control samplings were also made. Sampling of control individuals was conducted on separate fishing trips at each season, before the test group was sampled. Tow duration was set at 1 hour to prevent physical damage (Milligan et al., 2009). Living Nephrops were sampled among the undersized Nephrops and put in trays with individual cells $(35 \mathrm{~mm} \times 35 \mathrm{~mm} \times 200 \mathrm{~mm}$ ) (Fig. 2) in on-board tanks. Once landed, these Nephrops were kept in onshore tanks until stabilisation of mortality was observed. Then a set of individuals with a sex ratio of about 50:50 were selected and these were placed in the on-board tanks during the sampling of the test group and have undergone the same protocol as the test group sampling. 


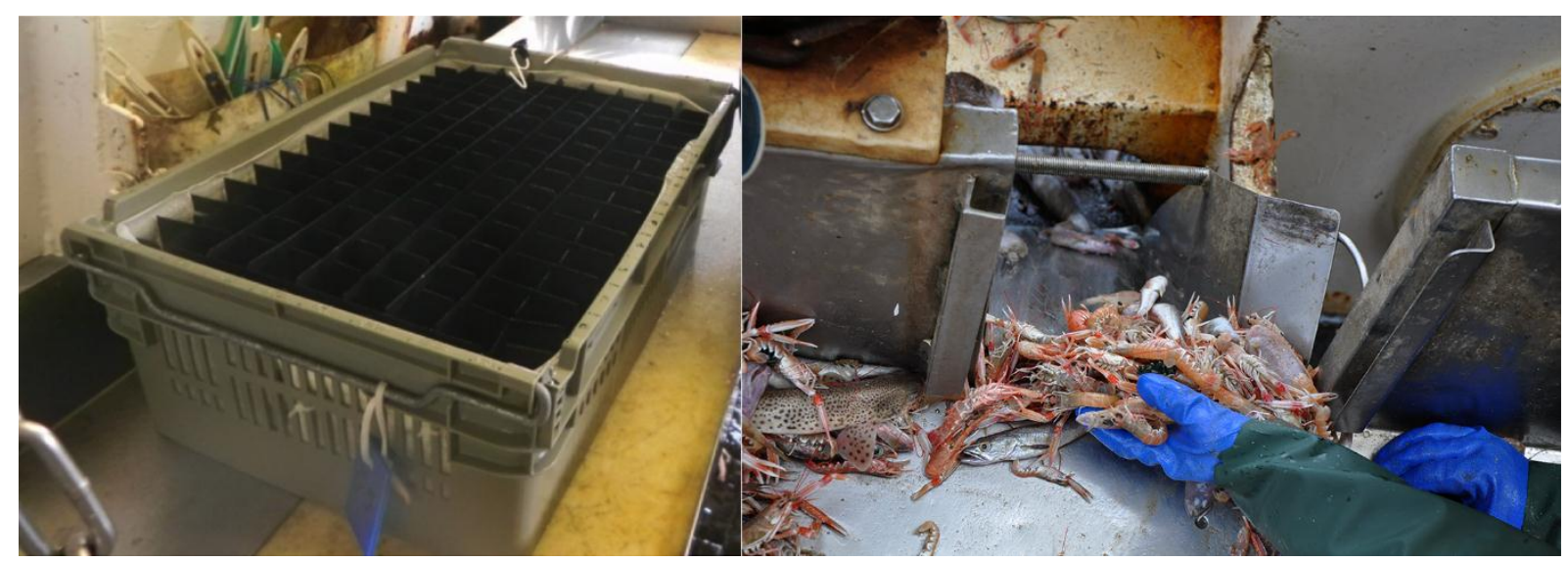

Figure 2:Tray with individual cells in which Nephrops were kept during the monitoring period (left panel) and example of discarding chute system onboard a commercial trawler (right panel). Credits: T.Rimaud and T.Evain.

\subsubsection{Test group sampling}

Nephrops were randomly sampled among the discarded individuals following two different sorting processes: (1) to simulate the standard sorting scenario individuals were collected at the end of the sorting process and (2) to simulate the discarding chute system sorting scenario (Fig. 2), individuals were sampled every 10 minutes. Both sorting processes were implemented during each fishing operation. Nephrops were placed in the trays and immerged in the on-board tanks. When a sampled individual was found to be dead, the corresponding cell in the tray was left empty. Cephalothoracic length $(\mathrm{mm})$, sex and presence of injuries (cuts on the tail, smashed Nephrops, broken rostrum, necrosis stains and holes in the carapace) were recorded at the death of the Nephrops or at the end of the monitoring period.

Environmental variables and characteristics of the fishing operation were recorded at each haul (Table 1). 
Table 1: Summary of the environmental and fishing operation related variables. For control individuals, the number in the column "Number of Nephrops sampled" is the one of Nephrops taken on board during the test sampling.

\begin{tabular}{|c|c|c|c|c|c|}
\hline Season & $\begin{array}{l}\text { Fishing } \\
\text { operation }\end{array}$ & $\begin{array}{l}\text { Air } \\
\text { temperature } \\
\left({ }^{\circ} \mathrm{C}\right)\end{array}$ & $\begin{array}{l}\text { Sorting } \\
\text { scenario }\end{array}$ & $\begin{array}{l}\text { Air exposure } \\
\text { min and max } \\
(\mathrm{h}: \min )\end{array}$ & $\begin{array}{l}\text { Number of } \\
\text { Nephrops } \\
\text { sampled }\end{array}$ \\
\hline \multirow{7}{*}{ Spring } & & 11.4 & Control & $00: 58$ to $01: 13$ & 131 \\
\hline & \multirow{2}{*}{1} & \multirow{2}{*}{15.7} & Standard & $01: 36$ to $01: 58$ & 264 \\
\hline & & & Chute system & $00: 45$ to $01: 49$ & 260 \\
\hline & \multirow{2}{*}{2} & \multirow{2}{*}{16.2} & Standard & $01: 15$ to $01: 34$ & 267 \\
\hline & & & Chute system & $00: 27$ to $01: 10$ & 264 \\
\hline & \multirow{2}{*}{3} & \multirow{2}{*}{19.1} & Standard & $01: 03$ & 132 \\
\hline & & & Chute system & $00: 25$ to $01: 09$ & 263 \\
\hline \multirow{13}{*}{ Summer } & \multirow{3}{*}{4} & 16.5 & Control & $00: 30$ to $02: 02$ & 255 \\
\hline & & \multirow{2}{*}{15.7} & Standard & $01: 23$ & 130 \\
\hline & & & Chute system & $00: 31$ to $01: 02$ & 131 \\
\hline & \multirow{2}{*}{5} & \multirow{2}{*}{16.2} & Standard & $01: 05$ & 131 \\
\hline & & & Chute system & $00: 13$ to $00: 43$ & 131 \\
\hline & \multirow{2}{*}{6} & \multirow{2}{*}{19.1} & Standard & $01: 19$ & 122 \\
\hline & & & Chute system & $00: 27$ to $01: 01$ & 133 \\
\hline & 7 & 19.9 & Chute system & $00: 16$ to $00: 48$ & 127 \\
\hline & \multirow{3}{*}{8} & \multirow{3}{*}{19.2} & Standard & $01: 13$ & 125 \\
\hline & & & Standard & $01: 35$ & 133 \\
\hline & & & Chute system & $00: 27$ to $00: 58$ & 122 \\
\hline & \multirow{2}{*}{9} & \multirow{2}{*}{20.1} & Standard & $01: 03$ & 129 \\
\hline & & & Chute system & $00: 16$ to $00: 48$ & 129 \\
\hline \multirow{12}{*}{ Autumn } & \multirow{3}{*}{10} & $\mathrm{NA}$ & Control & $00: 48$ to $00: 52$ & 128 \\
\hline & & \multirow{2}{*}{20.6} & Standard & $01: 15$ & 132 \\
\hline & & & Chute system & $00: 30$ to $01: 00$ & 131 \\
\hline & \multirow{2}{*}{11} & \multirow{2}{*}{19.0} & Standard & $01: 17$ & 131 \\
\hline & & & Chute system & $00: 29$ to $01: 00$ & 128 \\
\hline & \multirow{2}{*}{12} & \multirow{2}{*}{18.9} & Standard & $01: 17$ & 130 \\
\hline & & & Chute system & $00: 27$ to $00: 56$ & 129 \\
\hline & \multirow{2}{*}{13} & \multirow{2}{*}{18.0} & Standard & $01: 08$ & 129 \\
\hline & & & Chute system & $00: 25$ to $00: 56$ & 126 \\
\hline & \multirow{2}{*}{14} & \multirow{2}{*}{19.5} & Standard & $01: 12$ & 131 \\
\hline & & & Chute system & $00: 31$ to $00: 58$ & 130 \\
\hline & 15 & 21.5 & Chute system & $00: 29$ to $00: 57$ & 130 \\
\hline Total & & & & & 4934 \\
\hline
\end{tabular}

\subsubsection{Experimental set up}

The on-board tanks on both sampling vessels were approximately $2 \mathrm{~m}^{3}$ and were equipped with bubbler systems. The water flowing in was pumped close to the surface and cooled to reach the temperature measured on the seabed at the sampling sites location. The onshore holding facilities were located in the port of Lorient, so air exposure during the transit from the vessel to the onshore tanks only lasted a few minutes. In the onshore facilities, control and test trays were randomly 
distributed between two tanks of $0.7 \mathrm{~m}^{3}$ each, whose temperature was set to the value recorded at the sampling sites. Salinity, temperature and nutrient concentrations were checked on a regular basis to ensure no variations could impair Nephrops survival. In addition, tanks were filled with pumped seawater that was biofiltrated and recirculated during the experiment. They were equipped with a bubbler system and a cover to maintain Nephrops into the dark. Nephrops were not fed, based on their demonstrated ability to endure a monitoring period without food (Valentinsson and Nilsson, 2015) and the potential stress induced by an inadequate alimentation.

\subsection{Vitality assessment}

Vitality was assessed visually, based on the three vitality levels defined in Méhault et al. (2016), developed based on unstressed Nephrops reactions: (1) healthy: the Nephrops has some strength in its body, moves without stimulus and is able to do a 'tail-flip'; (2) moribund: the Nephrops moves slowly or only if stimulated, only its appendages move; (3) dead: the Nephrops does not move at all and shows no reaction to stimuli. The vitality state of each Nephrops was recorded on a daily basis over 14 days. Individuals that were not moving were gently stimulated with long curved tweezers and if they did not react, they were put into a water-filled tray with large cells for further examination. Dead individuals were removed from the trays.

\subsection{Data analysis}

\subsubsection{Survival rate}

Survival rate was calculated for each sampling scenario and for the controls, based on the proportion of Nephrops alive at the end of the captivity period. The 
survival rate was computed for each season and for the three seasons pooled together. The moribund Nephrops $(0.7 \%$ of the total sampled individuals at the end of the experimentation) were counted as alive and a $95 \%$ confidence interval $(\mathrm{Cl})$ was calculated for each survival rate (mean $\pm 1.96 \times S D$.).

\subsubsection{Kaplan-Meier plots}

Over the captivity period, we recorded the day on which each Nephrops died and at the end of the experimentation, we recorded which individuals had survived. This kind of data is known as right-censored data, because death was not necessarily observed during the experimentation, and can be analysed by a KaplanMeier estimation. Kaplan-Meier estimator allows visualising the proportion of survival with time. Plots were realised for each of the three seasons and on the three seasons pooled together, with their corresponding $95 \%$ confidence interval. The difference between the curves of the two sorting scenarios was tested with a log-rank test. Analyses were conducted with the "survival" package, in R 3.3.1 (R Development Core Team, 2016).

\subsubsection{Generalized linear model analysis}

A generalized linear model (GLM) was used to investigate which environmental, biological or technical parameters influenced the survival rate of discarded Nephrops. We fitted the GLM with a binomial distribution and a logit link

function to the survival from the $1^{\text {st }}$ day of captivity to the end of experimentation. Live Nephrops were coded 0 and dead Nephrops coded 1. Explanatory variables included 
in the GLM were season, duration of air exposure, catch composition, presence of injuries, sex and length. The model can be expressed as shown in Eq. 1.

(1) $\operatorname{logit}\left(P\left(Y_{i}=1 \mid \mathrm{X}_{\mathrm{i}}\right)\right)=\beta_{0}+\mathrm{X}_{i} \vec{\beta}$

With $P\left(Y_{i}=1 \mid \mathrm{X}_{\mathrm{i}}\right)$ the probability for Nephrops $i$ to be dead at day 14 knowing the design matrix of the covariates $X_{i} ; \beta_{0}$ the intercept; $\vec{\beta}$ the vector of the coefficients

The best model was selected with a stepwise procedure based on the minimization of the Akaike Information Criterion (AIC). For the qualitative variables injury (coded as "Yes" or "No") and season, the modality "No" of the variable injury and the modality "Autumn" of the variable season were taken as references in the summary output. Nagelkerke's pseudo $\mathrm{R}^{2}$ was used to quantify the variance explained by the model (Nagelkerke 1991).

\section{Results}

A total of 4934 Nephrops were sampled, with 1581, 1798 and 1555 individuals in spring, summer and autumn, respectively. This number includes the 131 control Nephrops sampled in spring, 255 in summer and 128 in autumn. Cephalothoracic length ranged from 15 to $33 \mathrm{~mm}$ (mean $24.3 \pm 2.7 \mathrm{~mm}$ ) with a mean length of $22.8 \pm 2.8$ $\mathrm{mm}, 25.2 \pm 2.4 \mathrm{~mm}$, and $24.3 \pm 2.4 \mathrm{~mm}$ in spring, summer and autumn, respectively (significant pairwise difference). The percentage of injured Nephrops was the highest in summer $(26.6 \%)$ and the lowest in spring (11.2\%) with a significant difference between these two seasons. The sex ratio was balanced at all seasons. Catch composition was significantly different between all seasons, with a higher value of catch composition index in spring $(0.29 \pm 0.08)$ compared with autumn $(0.12 \pm 0.03)$ 
and summer $(0.11 \pm 0.06)$. For each of the two sorting scenarios, duration of the air exposure significantly varies between seasons, with a longer air exposure in spring $(0.92 \pm 0.33 \mathrm{~h}$ for chute system; $1.41 \pm 0.31 \mathrm{~h}$ for standard) compared with summer $(0.61 \pm 0.23 \mathrm{~h}$ for chute system; $1.30 \pm 0.16 \mathrm{~h}$ for standard $)$ and autumn $(0.71 \pm 0.18 \mathrm{~h}$ for chute system; $1.23 \pm 0.06 \mathrm{~h}$ for standard). Finally, air temperature was significantly different between all seasons, with a mean of $16.4 \pm 2.0^{\circ} \mathrm{C}$ in spring, $19.6 \pm 1.4^{\circ} \mathrm{C}$ in summer and $19.4 \pm 1.1^{\circ} \mathrm{C}$ in autumn.

In addition, the number of injured Nephrops was significantly different between sorting scenarios $\left(\mathrm{Chi}^{2}\right.$ test, $\mathrm{Chi}^{2}=10.595, \mathrm{p}$-value $\left.=0.0011\right)$, with a higher number of injured individuals with the standard sorting scenario $(20.7 \%)$ than with the discarding chute system (17.7\%). Mean air exposure was significantly lower with the chute system scenario $(0.75 \mathrm{~h})$ compared with the standard one $(1.34 \mathrm{~h})$ (t-test, $\mathrm{t}=$ 74.1, p-value $<0.0001$ ). At the end of the on board sampling at day 0, Nephrops sorted with the discarding chute system showed a percentage of dead individuals two times lower than the ones sorted with the standard scenario as well as a higher percentage of healthy individuals (Table 2). The percentage of moribund individuals was similar between the two sorting scenarios (Table 2).

Table 2: Percentage of dead, moribund and healthy Nephrops at day 0, according to the sorting scenario.

\section{Vitality state at day 0}

(\% of total number of Nephrops in each sorting scenario)

\begin{tabular}{llll} 
Sorting scenario & Dead & Moribund & Healthy \\
\hline Standard & 33.0 & 31.3 & 35.7 \\
\cline { 2 - 4 } Discarding chute system & 15.6 & 34.8 & 49.6 \\
\hline
\end{tabular}

Examination of the survival rates for each season revealed that mortality stabilized after day 5 and that this stabilisation was not as marked in spring as in 
summer or autumn since the slopes of the survival curves between day 6 and day 14 were smaller in summer and autumn (Fig. 3, A, B, C). For each season, the two sorting scenarios were significantly different and the survival rate of the individuals sorted with the discarding chute system was always higher than the one of individuals sorted with the standard scenario. The difference between the two sorting scenarios was lower in spring $\left(\mathrm{Chi}^{2}=7.7, \mathrm{p}\right.$-value $\left.=0.006\right)$ than in summer $\left(\mathrm{Chi}^{2}=\right.$ 71.3, p-value $<0.0001)$ and autumn $\left(\mathrm{Chi}^{2}=54.7, \mathrm{p}\right.$-value $\left.<0.0001\right)$. Overall, for the three seasons pooled together (Fig. 3, D), the stabilisation of the survival rate was reached at day 5 and the survival rate was significantly different between the two sorting scenarios $\left(\mathrm{Chi}^{2}=116, \mathrm{p}\right.$-value $\left.<0.0001\right)$. At all seasons, control Nephrops underwent a lower mortality than the test individuals did.

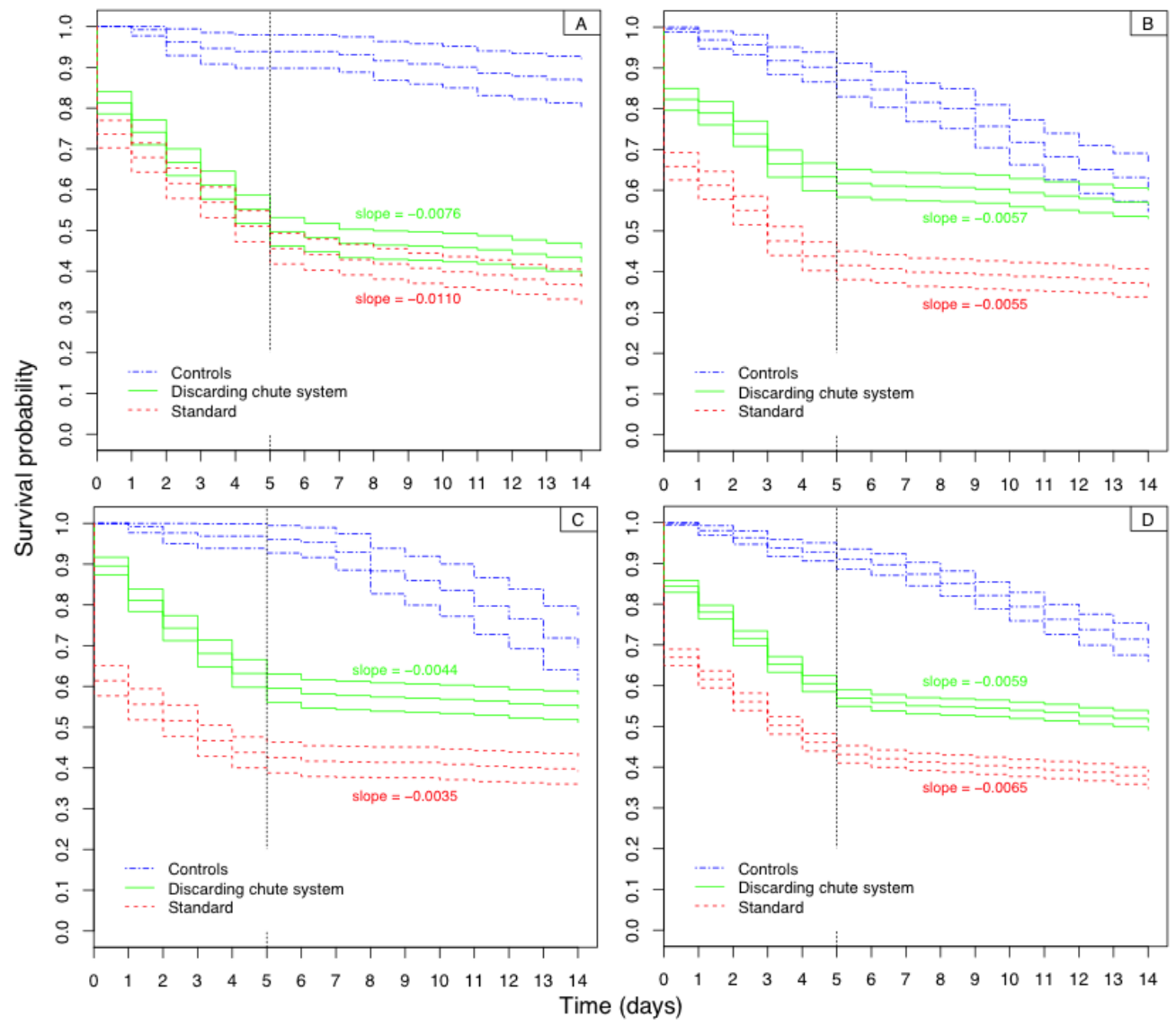

Figure 3:Kaplan-Meier estimation plots: survival probability as a function of time for spring (A), summer (B), autumn (C) and the three seasons pooled together (D). For each scenario, the survival curve is framed by a $95 \%$ confidence interval. The slope of the survival curve between days 5 and 14 for the 2 sorting scenarios is indicated beside each curve. 
At the end of the 14 days monitoring period, for all seasons pooled together, the individuals sorted with the discarding chute system showed a survival rate of $51.2 \%[30.9 ; 71.5 \%]$ while individuals sorted with the standard scenario had a lower survival rate of $36.9 \%$ [20.9; $52.9 \%$ (Table 3). Survival rate was slightly lower in spring, especially for the discarding chute system scenarios. Controls showed a survival rate of $86.3 \%$ in spring, $61.8 \%$ in summer and $69.5 \%$ in autumn.

Table 3: Survival rates (\%) and their 95\% confidence intervals [in square brackets] at the end of the monitoring period for the two sorting scenarios and control

\begin{tabular}{llll}
\hline Season & Standard scenario & $\begin{array}{l}\text { Discarding chute } \\
\text { scenario }\end{array}$ & Control \\
\hline Spring & $35.4[15.3 ; 55.5]$ & $42.3[26.6 ; 57.9]$ & 86.3 \\
Summer & $36.4[30.3 ; 42.5]$ & $56.5[49.3 ; 63.7]$ & 61.8 \\
Autumn & $39.2[17.5 ; 60.9]$ & $54.9[31.5 ; 78.3]$ & 69.5 \\
\hline Global & $36.9[20.9 ; 52.9]$ & $51.2[30.9 ; 71.5]$ & $69.3[45.7 ; 93.0]$ \\
\hline
\end{tabular}

The results of the GLM indicate that the variables injury, season and duration of the air exposure, significantly influence the survival from the $1^{\text {st }}$ day of captivity to the end of the monitoring period (Table 4). Presence of injuries and long air exposure reduce survival rate. Survival is highest in summer, then in autumn and lower in spring. 
Table 4: Chi2 statistics and p-value indicate the significance of the variables in the best model. For each modality, the slope and standard deviation give the sign of the relation with survival at day 14. A positive slope indicates a positive relationship between the covariate and the survival which value 1 means death.

\begin{tabular}{llllll}
\hline Variable & Slope & $\begin{array}{l}\text { Standard } \\
\text { deviation }\end{array}$ & Chi $^{2}$ stat & $\mathbf{p}$ & Significance \\
\hline $\begin{array}{l}\text { Injury } \\
\quad \text { injuryYes }\end{array}$ & 1.24 & 0.11 & 147.46 & $<2.2 . \mathrm{e}^{-16}$ & $* * *$ \\
$\quad \begin{array}{l}\text { Duration air exposure } \\
\text { Season }\end{array}$ & 0.33 & 0.10 & 11.83 & $5.85 . \mathrm{e}^{-4}$ & $* * *$ \\
$\quad \begin{array}{l}\text { seasonSUMMER } \\
\quad \text { seasonSPRING }\end{array}$ & -0.12 & 0.09 & 48.88 & $2.44 . \mathrm{e}^{-11}$ & $* * *$ \\
$\quad$\begin{tabular}{l} 
Cephalothoracic length \\
\hline
\end{tabular} & 0.52 & 0.09 & & & \\
& 0.02 & 0.01 & 2.12 & 0.15 & NS \\
\hline
\end{tabular}

\section{Discussion}

In the context of sustainable management of marine resources, it is particularly important to limit non-target catches and favour the survival of discards. Our experiment offers new data on the survival rate of Nephrops discarded by trawlers in the Bay of Biscay. The result of $36.9 \%$ survival for the standard catch handling process for all seasons pooled together is in line with studies in other European Nephrops fisheries that used a similar method and monitoring period: $55 \%$ in Sweden (Valentinsson and Nilsson, 2015) and 62\% in the UK (Armstrong et al., 2016). Moreover, to be consistent with Nephrops fishery evolution, we tested the use of a discarding chute system, which limits the duration of the air exposure as well as the possibility for the Nephrops of being injured on the deck. We demonstrated a significantly shorter air exposure and smaller number of injured Nephrops with the discarding chute scenario and our results highlighted the efficiency of this device since it led to a survival rate of $51.2 \%$ compared with the $36.9 \%$ for standard sorting practices.

The negative relationship between survival rate and injuries, already mentioned in previous studies (Albalat et al. 2016; Campos et al., 2015; Ridgway et al., 2006b; Wileman et al., 1999), is confirmed here and can be explained by a loss of 
haemolymph (Harris and Andrews 2005). Similarly, long air exposure is known to decrease survival (Harris and Andrews 2005; Méhault et al., 2016; Ridgway et al., 2006a), possible via dehydration and a reduction in the immune function (Harris and Andrews 2005; Ridgway et al., 2006a). Survival rate is significantly different between seasons and the highest rates occur in summer and autumn. This could be linked to the slightly higher duration of air exposure endured in spring or to the annual moulting period between February and May (Field et al., 1992), with a peak in AprilMay in our study. At this stage, it has been shown that decapods suffer more severe damage due to softness of their exoskeletons (Milligan et al., 2009; Ridgway et al., 2006b) and even suffer greater mortality (Wassenberg and Hill 1989). However, one should take with caution the higher mortality in spring demonstrated in the results of the GLM. Indeed, Nephrops suffered a lower mortality at day 0 in spring compared with summer and autumn but had then a sharper decrease of the survival rate (Fig. 3). This delayed mortality contributed to wider the difference between slopes of the modality "spring" and "summer" ("autumn" taken as a reference) of the season qualitative variable (Table 4). Overall, the GLM model explains a small part of the total variance (Nagelkerke's pseudo $\mathrm{R}^{2}=0.08$ ) so that the variance at the individual level may prevail over the variance explained by the explanatory variables of the GLM.

Because of experimental conditions, under- or over-estimation of survival rates may occur. First, in a study based on onshore monitoring, it is impossible to account for the predation pressure on Nephrops, or their ability to survive in their natural environment (burrowing, escaping predators, etc.) (Castro et al., 2003; STECF 2015). According to Albalat et al. (2016) who placed underwater camera to observe the behaviour of discarded Nephrops, the healthy individuals are able to stand, move 
and actively avoid predators by repeated tail-flips within a few minutes after their return to the bottom. The higher percentage at day 0 of healthy individuals in Nephrops sorted with the chute system compared with the standard scenario confirms the efficiency of such a device to enhance the survival of Nephrops in real fishing conditions. Mortality might also have been overestimated due to additional stress from the condition of captivity: starvation, restriction of movement and impossibility of burrowing behaviour (Castro et al., 2003), or the manipulation for daily vitality assessment as well as the stress induced by the transportation from the onboard to the onshore tanks. In addition, the sampling protocol also decreased the beneficence that the discarding chute system would have in real fishing condition due to the air exposure undergone by sampled Nephrops every time new individuals had to be added to the tray.

Finally, control Nephrops were caught and kept in a tank until stabilisation of survival prior to the test experiment, and endured between 21 and 31 days of starvation. The $69.3 \%$ survival rate obtained using trawl-caught control Nephrops is lower than the rate obtained in other studies that used creel-caught controls (Armstrong et al., 2016; Campos et al., 2015; Valentinsson and Nilsson 2015). This difference in survival could be explained by a difference in cephalothoracic length and in duration of the captivity period. Indeed, creel caught Nephrops are larger than the trawl-caught ones (Campos et al., 2015) and suffer very little stress from being caught (Ridgway et al., 2006b), so they do not have to handle an additional captivity period to reach a stabilisation of the survival. In this study, trawl-caught controls were preferred for consistency in size classes of individuals. Since no effect of cephalothoracic length on the survival at the end of the experimentation have been demonstrated, the $69.3 \%$ survival rate obtained and the absence of survival rate 
stabilisation observed for the controls most likely originates in the duration of the starvation period. Test individuals that spent only 14 days in captivity do not seem to suffer the same absence of stabilisation of mortality as controls since their survival rate shows a clear stabilisation. For this reason, the mortality suffered by control individuals is distinguished from the one underwent by test Nephrops and does not cast doubt on the survival rates obtained with the test individuals.

The longer monitoring period (14 days) compared with previous studies conducted in the same area (3 days for Gueguen and Charuau 1975 and Méhault et al., 2016) allowed us to reach the asymptote of survival rate for the test Nephrops. This made it possible to ensure that delayed mortality was taken into account and strengthen the reliability of our results. We provided an accurate survival rate estimate, which is the prerequisite to apply for an exemption from the discard ban and to propose mitigations measures. Despite our study demonstrates the capacity of Nephrops to survive after discard, little is known about Nephrops' ability to actually avoid predation and find a new burrow when discarded back to the seabed. An underwater video record, such as the methodology used in Albalat et al. (2016), could provide some insight for the Nephrops fishery of the Bay of Biscay.

\section{Acknowledgements}

This project was funded by the French ministry of Environment, Energy and the Sea, France Filière Pêche, IFREMER and the French regions Bretagne, Pays de la Loire and Nouvelle Aquitaine. The authors gratefully acknowledge the crews of the Côte d'Ambre and the Men Gwen for their collaboration in the sampling process as well as the S.E.M. Lorient-Keroman who provided the inshore tank facilities. 


\section{References}

Albalat, A., Sinclair, S., Laurie, J., Taylor, A., Neil, D., 2010. Targeting the live market: Recovery of Norway lobsters Nephrops norvegicus from trawl-capture as assessed by stress-related parameters and nucleotide breakdown. J. Exp. Mar. Biol. Ecol. 395, 206-214. doi:10.1016/j.jembe.2010.09.002

Albalat, A., Collard, A., Mcadam, B., Coates, C.J., Clive, J., 2016. Physiological condition, short term survival and predator avoidance behaviour of discarded Norway lobsters (Nephrops norvegicus). J. Shellfish Res. 35(4):1053-1065. doi:10.2983/035.035.0428

Armstrong, F., Randall, P., Ribeiro Santos, A., Jones, P., Firmin, C., Doran, S., Catchpole, T., 2016. Assessing the survival of discarded Nephrops in the English NE Nephrops selective trawl fishery, ASSIST MF1232, CEFAS report. Available at: http://www.nsrac.org/wp-content/uploads/2016/04/Paper-4.1Annexes_HLG_NS_JR_discardplan_demersal_20160520.pdf, 23.12.16.

Bergmann, M., Moor, P.G., 2001. Survival of decapod crustaceans discarded in the Nephrops fishery of the Clyde Sea area, Scotland. ICES J. Mar. Sci. 58, 163171. doi:10.1006/jmsc.2000.0999

Campos, A., Fonseca, P., Pilar-Fonseca, T., Leocádio, A.M., Castro, M., 2015.

Survival of trawl-caught Norway lobster (Nephrops norvegicus) after capture and release - Potential effect of codend mesh type on survival. Fish. Res. 172, 415422. doi:10.1016/j.fishres.2015.07.038 
Castro, M., Araújo, A., Monteiro, P., Madeira, A.M., Silvert, W., 2003. The efficacy of releasing caught Nephrops as a management measure. Fish. Res. 65, 475-484. doi:10.1016/j.fishres.2003.09.033

Chapman, C.J., Shelton, P.M.J., Shanks, A.M., Gaten, E., 2000. Survival and growth of the Norway lobster Nephrops norvegicus in relation to light-induced eye damage. Mar. Biol. 136, 233-241. doi:10.1007/s002270050681

Cornou, A.-S., Diméet, J., Goascoz, N., Quinio-Scavinner, M., Rochet, M.-J., 2016. Captures et rejets des métiers de pêche français - Résultats des observations à bord des navires de pêche professionnelle en 2015. Available at : http://archimer.ifremer.fr/doc/00353/46441/. 06.01.2017, 14.01.16.

European Commission, 2006.Council Regulation (EC) No 56/2006 of 22 December 2005 fixing for 2006 the fishing opportunities and associated conditions for certain fish stocks and groups of fish stocks, applicable in Community waters and, for Community vessels, in waters where catch limitations are required. Off. J. Eur. Union. Available at http:// http://eur-lex.europa.eu/legalcontent/EN/TXT/?qid=1487687569065\&uri=CELEX:32006R0051, 20.02.17.

European Commission, 2013. Regulation (EU) No 1380/2013 of the European parliament and of the council of 11 December 2013 on the common fisheries policy. Off. J. Eur. Union. Available at http://eur-lex.europa.eu/legalcontent/EN/TXT/?uri=celex\%3A32013R1380", 02.02.17.

Field, R.H., Chapman, C.J., Taylor, A.C., Neil, D.M., Vickerman, K., 1992. Infection of the Norway lobster Nephrops norvegicus by a Hematodinium-like species of dinoflagellate on the west coast of Scotland. Dis. Aquat. Organ. 13, 1-15. 
Gaten, E., Moss, S., Johnson, M.L., 2013. The reniform reflecting superposition compound eyes of Nephrops norvegicus: optics, susceptibility to light-induced damage, electrophysiology and a ray tracing model, in: Magnus, L.J., Mark, P.J. (Eds.), The Ecology and Biology of Nephrops norvegicus. Adv Mar Biol. 64, 107148.

Giomi, F., Raicevich, S., Giovanardi, O., Pranovi, F., Di Muro, P., Beltramini, M., 2008. Catch me in winter! Seasonal variation in air temperature severely enhances physiological stress and mortality of species subjected to sorting operations and discarded during annual fishing activities. Hydrobiologia 606, 195-202.

Gueguen, J., Charuau, A., 1975. Essai de détermination du taux de survie des langoustines hors taille rejetées lors des opérations de pêche commerciale. ICES CM 1975/K:12.

Harris, R.R., Andrews, M.B., 2005. Physiological changes in the Norway lobster Nephrops norvegicus escaping and discarded from commercial trawls on the West Coast of Scotland: II. Disturbances in haemolymph respiratory gases, tissue metabolites and swimming performance after capture a. J. Exp. Mar. Bio. Ecol. 320, 195-210. doi:10.1016/j.jembe.2004.12.028

Harris, R.R., Ulmestrand, M., 2004. Discarding Norway lobster (Nephrops norvegicus) through low salinity layers - Mortality and damage seen in simulation experiments. ICES J. Mar. Sci. 61, 127-139. doi:10.1016/j.icesjms.2003.08.002

ICES, 2015. Report of the Workshop on Methods for Estimating Discard Survival 3 (WKMEDS 3), 20-24 April 2015, London, UK. ICES CM 2015\ACOM:39. p5. 
Available at :

http://www.ices.dk/sites/pub/Publication\%20Reports/Expert\%20Group\%20Repor t/acom/2015/WKMEDS/01\%20WKMEDS3\%20report\%20FINAL.pdf, 22.12.16.

JORF, 2008. Arrêté du 31 mars 2008 portant approbation d'une délibération du Comité national des pêches maritimes et des élevages marins portant application de l'article 6 de la délibération n³9/2007 du CNPMEM relative aux conditions d'exercice de la pêche de la langoustine (Nephrops norvegicus) dans les eaux du Golfe de Gascogne (division CIEM VIII a, b, d et e). J. off. Rép. française. Available at:

https://www.legifrance.gouv.fr/affichTexte.do?cidTexte=JORFTEXT0000186227 $\underline{23}, 21.01 .17$.

JORF, 2011. Arrêté du 9 décembre 2011 encadrant la pêche de la langoustine (Nephrops norvegicus) dans la zone CIEM VIII a, b, d et e. J. off. Rép. française. Available at:

https://www.legifrance.gouv.fr/eli/arrete/2011/12/9/AGRM1129620A/jo, 21.01.17.

JORF, 2016. Arrêté du 27 mai 2016 fixant les modalités de gestion des régimes d'autorisations européennes et nationales de pêche contingentées pour l'exercice de la pêche professionnelle en zone FAO 27. J. off. Rép. française. Available at:

https://www.legifrance.gouv.fr/affichTexte.do?cidTexte=JORFTEXT0000326282 97\&categorieLien=id, 21.01 .16$.

Leblond, E., Daurès, F., Léonardi, S., Demaneche, S., Merrien, Cl., Berthou, P., PitelRoudaut, M., Macher, C., Lespagnol, P., 2012. Synthèse des flottilles de pêche 
2012. Available at : http://archimer.ifremer.fr/doc/00248/35971/34497.pdf, 20.12.2016.

Lund, H.S., Wang, T., Chang, E.S., Pedersen, L.F., Taylor, E.W., Pedersen, P.B., Mckenzie, D.J., 2009. Recovery by the Norway lobster Nephrops norvegicus from the physiological stresses of trawling : Influence of season and live-storage position. J. Exp. Mar. Bio. Ecol. 373, 124-132. doi:10.1016/j.jembe.2009.04.004

Méhault, S., Morandeau, F., Kopp, D., 2016. Survival of discarded Nephrops norvegicus after trawling in the Bay of Biscay. Fish. Res. 183, 396-400. doi:10.1016/j.fishres.2016.07.011

Milligan, R.J., Albalat, a., Atkinson, R.J.A., Neil, D.M., 2009. The effects of trawling on the physical condition of the Norway lobster Nephrops norvegicus in relation to seasonal cycles in the Clyde Sea area. ICES J. Mar. Sci. 66, 488-494. doi:10.1093/icesjms/fsp018

Nagelkerke, N.J.D., 1991. A note on a general definition of the coefficient of determination. Biometrika 78, 691-692. doi:10.1093/biomet/78.3.691

R Development Core Team, 2016. R: A language and environment for statistical computing. R Foundation for Statistical Computing, Vienna, Austria. URL https://www.R-project.org/.

Ridgway, I.D., Taylor, A.C., Atkinson, R.J.A., Stentiford, G.D., Chang, E.S., Chang, S.A., Neil, D.M., 2006a. Morbidity and mortality in Norway lobsters, Nephrops norvegicus: Physiological, immunological and pathological effects of aerial 
exposure. J. Exp. Mar. Bio. Ecol. 328, 251-264.

doi:10.1016/j.jembe.2005.07.015

Ridgway, I.D., Taylor, A. C., Atkinson, R.J.A., Chang, E.S., Neil, D.M., 2006b. Impact of capture method and trawl duration on the health status of the Norway lobster, Nephrops norvegicus. J. Exp. Mar. Bio. Ecol. 339, 135-147. doi:10.1016/j.jembe.2006.07.008

STECF, 2013. Landing obligation in EU fisheries (STECF-13-23). 2013. Publications Office of the European Union, Luxembourg, EUR 26330 EN, JRC 86112, 115 pp. Available at: https://stecf.jrc.ec.europa.eu/documents/43805/610582/201311_STECF+13-23+-+Landing+obligation+in+EU+Fisheriespart1_JRC86112.pdf, p24, 21.12.16.

STECF, 2015. Landing Obligation -Part 5 (demersal species for NWW, SWW and North Sea) (STECF-15-10) 2015. Publications Office of the European Union, Luxembourg, EUR 27407EN, JRC 96949, 62pp. Available at: https://stecf.jrc.ec.europa.eu/documents/43805/999871/2015-07_STECF+1510+-+Landing+obligations+-+part+5_JRC96949.pdf, p6, 21.12.16.

Valentinsson, D., Nilsson, H.C., 2015. Effects of gear and season on discard survivability in three Swedish fisheries for Norway lobster (Nephrops norvegicus). Swedish University of Agricultural Sciences. 1-11.

Vogel, C., Kopp, D., Méhault, S., 2017. From discard ban to exemption: How can gear technology help reduce catches of undersized Nephrops and hake in the Bay of Biscay trawling fleet? J. Environ. Manage. 186, 96-107. doi:10.1016/j.jenvman.2016.10.017 
Wassenberg, T.J., Hill, B.J., 1989. The effect of trawling and subsequent handling on the survival rates of the by-catch of prawn trawlers in Moreton Bay, Australia. Fish. Res. 7, 99-110. doi:10.1016/0165-7836(89)90010-6

Wileman, D.A., Sangster, G.I., Breen, M., Ulmestrand, M., Soldal, A.V., Harris, R.R., 1999. Roundfish and Nephrops survival after escape from commercial fishing gear. Final Report-EC Contract No: FAIR-CT95-0753. 